\title{
E-Learning Success Model: An Extention of DeLone \& McLean IS' Success Model
}

\author{
Henki Bayu Seta ${ }^{1}$, Theresia Wati ${ }^{2}$, Anita Muliawati ${ }^{3}$, Achmad Nizar Hidayanto $^{4}$ \\ ${ }^{123}$ Faculty of Computer Science UPN “Veteran” Jakarta, Jalan RS Fatmawati, Indonesia \\ ${ }^{4}$ Faculty of Computer Science, Universitas Indonesia, Indonesia
}

\begin{abstract}
Article Info
Article history:

Received May 23, 2018

Revised Aug 23, 2018

Accepted Sep 6, 2018

\section{Keyword:}

Education

E-learning

E-learning system success

Individual Impact

Use

ABSTRACT

Learning by using e-learning system at this time become an important part of university to carrying out the education. Learning by e-learning system is very supportive to conventional learning, so it is necessary to measure the success of e-learning implementation. In this article, the research model was developed by integrating. DeLone\& McLean IS concept of success model and adoption model of e-learning success. The variables that used in this research is technical system quality, service quality, content and information quality, use, user perceived satisfaction, and individual impact. Data collection is by conducting surveys to e-learning users which is lecturers and students. To test the model that has been developed, conducted a survey on UPN "Veteran" Jakarta with the total number of respondents as many as 180 respondents and obtained 157 respondents who fill the questionnaire correctly. This research, shows both the use and satisfaction of e-learning system have an impact for individual performance. This research also found that educational system quality and technical quality are the main factors that encourage user satisfaction with e-learning system, while the use of elearning system that influenced by content $\&$ information quality, also user perceived satisfaction for e-learning system.
\end{abstract}

Copyright @ 2018 Institute of Advanced Engineering and Science. All rights reserved.

\section{Corresponding Author:}

Theresia Wati,

Faculty of Computer Science, UPN Veteran Jakarta,

Jalan RS Fatmawati, Indonesia.

Email: theresiawati@upnvj.ac.id

\section{INTRODUCTION}

At this time, distance learning is constantly increased. According to the article at [1] the growth rate of e-learning in Indonesia occupies the $8^{\text {th }}$ position with the growth of $25 \%$ and $60 \%$ of the learning method by using e-learning, the learning time will be more effective and efficient. Tendency of the university to develop e-learning as one of the alternative learning is increasing. The infrastructure development, and the ease of internet access is no longer and obstacle to conduct teaching and learning process. Before university implement e-learning, the level of readiness of e-learning is required. According to [2], UPN "Veteran Jakarta has an average value of readiness using e-learning is 3.297 (not ready needs some works). The variables that have been declared that is ready are human resource and content variable. While the variables that are not ready are technology, organization, and financial. Some of the factors that must be prepared for the university is ready to implement e-learning such as technology (network, hardware and software), human resource (self and competence skill), organization (leadership and policy), and financial (fund allocation and financial policy).

The success of an e-learning system is determined by how far the e-learning system use and have impacts to the users. Various studies that have been conducted to evaluate the success of e-learning system, especially adapting from the information system success model that have been developed by DeLone and McLean [3], [4] as done by [5] and [6]. These studies found that satisfaction and use of e-learning had an 
impact on student performance in learning. Unfortunately, the research on the success of e-learning systems is rarely done in Indonesian context.

This research was conducted to build an integrated model of e-learning success in Indonesia. The model that proposed in this study was built by adapting the success model of information systems from DeLone\& McLean which proved in many studies is an appropriate model for assessing the success of information systems in various contexts. To conform the e-learning context, DeLone\& McLean model is adapted using variables Technical System Quality (TES), Educational System Quality (ESQ), Service Quality (SQ), Content \& Information Quality (CIQ), use, user perceived satisfaction (UPS) and individual impact.

To test the model, this research is done by taking data at UPN Veteran Jakarta which has implemented e-learning system in recent years. Through this research, it is hoped that the success model of elearning system will be more suitable to the Indonesian context.

\section{DELONE \& MCLEAN IS SUCCESS MODEL}

In 1992, DeLone\& McLean made the IS Success Model consisting of six factors that measuring the success of information systems that affect to each other. The model consists of six factors or variables that is system quality, information quality, satisfaction, use, individual impact, and organization impact. The measurement of the success variables of information systems can not be measured independently but must be as a whole. Variables that one will affect the other variables. Based on Figure 1, the quality of the system, and the quality of the information affect the user to use information systems and user satisfaction while using information systems. Variables of use and satisfaction of the use information systems will affect each other and will have an impact on the individual so as to improve the individual performance. Increased individual performance will have a good impact on the organization.

The quality of information systems is influenced by data accuracy, easy to use, convenience factor, user realization, system features and functionality, accurate, flexible, efficient, reliable, and sophisticated systems, system integration, has good response time and turnaround time. The quality of information can be measured by relevance, usefulness, informative, easy to understand, consistent, comprehensiveness, novelty of information, and not double meaning [3].

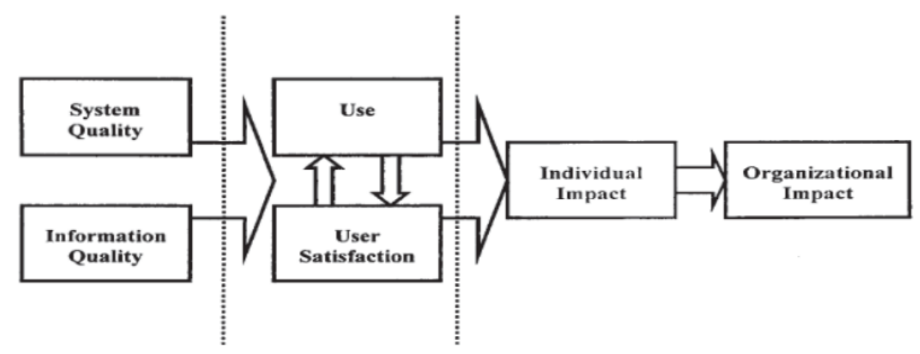

Figure 1. DeLone \& McLean IS success model [3]

In 2003, DeLone\& McLean updated the IS Success Model as shown in Figure 2. There is one additional variable that is quality of service that will affect users to use information systems and user satisfaction when using information systems. Quality of service can be measured through (assurance, empathy, and responsiveness).

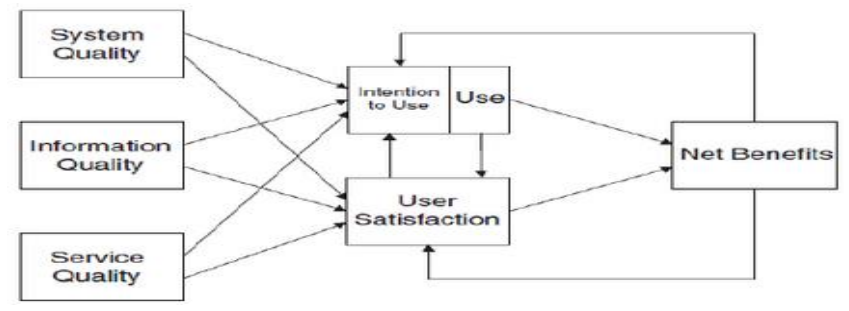

Figure 2. DeLone\& McLean IS success model [4] 
The individual impact and organization impact merge into one called net benefits. Net benefits are the benefits felt by the individual and will have an impact on the organization after using the information system. Information system user satisfaction will affect the interest to use information system and the use of information system will give satisfaction to the user. Net benefits will affect the interest to use and user satisfaction with the information system. Net benefits can be measured through cost savings, expanded markets, incremental additional, sales, reduced search costs, and time savings.

\section{CONSEPTUAL MODEL}

The research model has four e-learning quality constructs that play an important role as a direct determinant between use and user perceived satisfaction like, Technical System Quality (TES), Educational System Quality (ESQ), Service Quality (SQ), and Content \& Information Quality (CIQ) as can be seen in Figure 3. Technical System Quality (TES) measuring the quality of e-learning system techniques that related to system navigation, ease to finding information, structured, fast accessing, having security, flexibility, ease to integration with other systems, reliability which is high, has an interactive and structured design. Educational System Quality (ESQ) measuring the quality of educational system related to communication facilities, attendance, collaborative, and active learning, evaluation of learning, outcomes, communication facilities, storage and sharing documents, effective and efficient sharing of information. Serving Quality (SQ) measuring the quality of e-learning system services related to help desk support in the provision of assistance services and the speed of responding to complaints against problems that occur, available documents and other information in e-learning. Content \& Information (CIQ) measuring the quality of information and content from e-learning information system regarding usability, ease of understanding, reliability, timeliness, accuracy and organized.

While Use (U) describes the use of e-learning system for information retrieval, publication information, storage and sharing documents, communicate with colleagues and to support the lectures. User Perceived Satisfaction (UPS) describes user satisfaction preceptions of e-learning system related to e-learning system to support the field of study, effective and efficient and overall satisfied using e-learning system. Individual Impact (IM) shows the impact of e-learning on its users, either helping users to facilitate, complete tasks faster, improve productivity, and be able to work more effectively and efficiently.

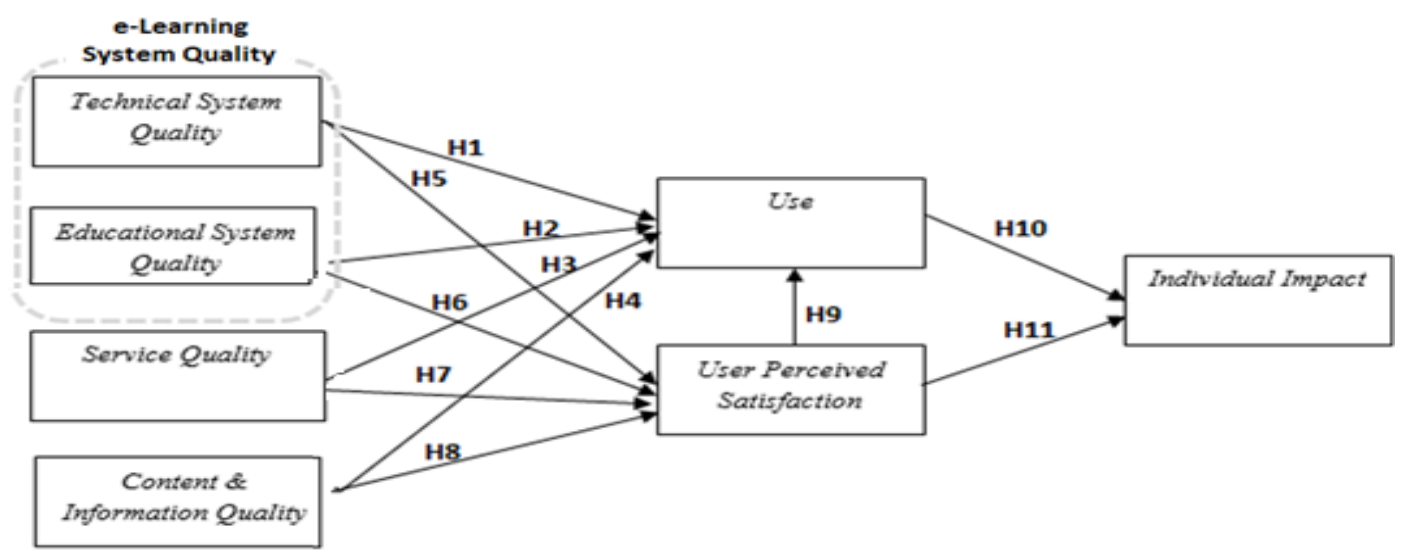

Figure 3. Research model

\subsection{Relationship between e-Learning System Quality and Use}

Research conducted by [6], found a positive relationship between information quality and use elearning system. The quality of information has significant impact on the use of e-learning for example the cource content. Good content criteria are easy to come by, useful, easy to understand, interesting, and reliable. If system has content and easy to navigate and well structured functionality, it will increase system usage. Through the translation, the authors suspect that there is a positive relationship between the quality of e-learning system with the use of e-learning system formulated in the following hypothesis:

H1: The quality of technical system affects the use of e-learning systems.

H2: The quality of education system affects the use of e-learning systems.

H3: Service quality affects the use of e-learning system.

H4: The quality of information and content affects the use of e-learning systems 


\subsection{Relationship between e-Learning System Quality and User Perceived Satisfaction}

According to [5] the quality of system techniques and the quality of the education system as well as the quality of information and content and affect to user satisfaction. There is a positive relationship between the quality of the engineering system, the quality of information \& content, and the quality of the education system with user satisfaction. Service quality is requirement of an e-learning system for efficient services, as measured by responsiveness, empathy, trust, and security [4][7].Quality of service is essential for satisfaction and use [8][9][10], and in the context of e-learning service quality positively impacts the use of e-learning and user satisfaction. The quality of the e-learning system includes the user's function, utility, navigation, and accessibility [6].Through the translation, the authors suspect there is a positive relationship between the quality of e-learning system with the perception of user satisfaction e-learning system formulated in the following hypothesis:

H5: The quality of the technical system affects the perceptions of user satisfaction of e-learning information systems.

H6: The quality of the education system affects the perceptions of user satisfaction of e-learning information systems.

H7: Service quality affects the perception of user satisfaction of e-learning information system.

H8: The quality of information and content affects the perception of user satisfaction of e-learning information systems.

\subsection{Relationship between Use, User Perceived Satisfaction and Individual Impact}

Many studies have used the Delone \& Mclean IS Success model in 1992 and expressed greater user satisfaction, the greater to individual impact [2] [7] [11]. The study of e-learning success reports that user satisfaction has a significant impact on values and positive impact on individual performance [12] [13]. User satisfaction is one measure of the successful use of an e-learning system to help their tasks, for example, retrieve and publish information and communicate with other[14]. The usefulness perception of the system used encourages the level of user satisfaction with the system. Through the translation, the authors suspect there is a positive relationship between the perception of user satisfaction with the use of e-learning system. And individual impacts are positively influenced by the use and perception of user satisfaction formulated in the following hypotheses:

H9: Perceptions of user satisfaction of e-learning information system affect the use of e-learning system.

H10: The intensity of the use of e-learning information systems will have an impact on individual users.

H11: Perceptions of user satisfaction e-learning information system will impact on individual users.

\section{RESEARCH METHOD}

Stages of research conducted on this research that is determination of research models and research hypotheses, the formation of questionnaires, testing the results of the questionnaire include validity test, realibility test model and hypotheses as can be seen in table 1 .

Table 1. Stages of Research

\begin{tabular}{|c|c|c|}
\hline Input & Process & Output \\
\hline $\begin{array}{l}\text { Jurnal, book, Internet } \\
\text { reference }\end{array}$ & Literature review & $\begin{array}{l}\text { Research model } \\
\text { Research hypothesis }\end{array}$ \\
\hline $\begin{array}{l}\text { Variabel and indicator } \\
\text { research }\end{array}$ & Research design & Questionnaire \\
\hline Questionnaire result & Data processing & $\begin{array}{l}\text { Test validity and reliability } \\
\text { Data Analysis } \\
\text { Testing models and hypotheses }\end{array}$ \\
\hline
\end{tabular}

\subsection{Instrument Variable Research}

The instrument used in this study is questionnaires using the likert scale 1 to 5 . Likert usage asks respondents to see a series of statements and express opinions. Details scale from scale 1 (strongly disagree), scale 2 (disagree), scale 3 (neutral), scale 4 (agree), and scale 5 (strongly agree). Table 2 contains a research instrument for analyzing the success factors of implementing e-learning systems at universities. Here's an explanation of the instruments. 
Table 2. Instrument Variable Research

\begin{tabular}{|c|c|c|c|}
\hline $\begin{array}{l}\text { Research } \\
\text { Variable }\end{array}$ & Dimension & Indicator & Source \\
\hline \multirow[t]{5}{*}{ Service Quality } & $\begin{array}{l}\text { Measurement service quality e-learning system } \\
\text { related support staff / help desk in the provision }\end{array}$ & $\begin{array}{l}\text { SQ1: help desk is responsible for providing service } \\
\text { and help whenever needed. }\end{array}$ & [6] \\
\hline & $\begin{array}{l}\text { of assistance services and speed to respond } \\
\text { complaints against problems that occur and }\end{array}$ & $\begin{array}{l}\text { SQ2: help desk gives attention or solution when have } \\
\text { a problems with e-learning. }\end{array}$ & [6] \\
\hline & $\begin{array}{l}\text { available documents and other information in e- } \\
\text { learning. }\end{array}$ & $\begin{array}{l}\text { SQ3: help desk provides services related to the e- } \\
\text { learning system at specified time }\end{array}$ & {$[17]$} \\
\hline & & $\begin{array}{l}\text { SQ4: have knowledge to answer questions related to } \\
\text { e-learning system. }\end{array}$ & [6] \\
\hline & & $\begin{array}{l}\text { SQ5: Available documents can be downloaded, } \\
\text { related courses, and other information }\end{array}$ & {$[5]$} \\
\hline Content & measurement of content & CIQ1: the content and information available in the e- & {$[5]$} \\
\hline
\end{tabular}

Information ind information quality of e-learning system related Quality to usability, ease of under-standing, reliability, time-linesss, accuracy and organized information and content.

Technical System Quality

Educational System Quality
Measurement of technical system quality elearning related to system navigation, ease of finding information, structured and easy to use. Fast access to e-learning system, has security, flexibility, ease of integration with other systems, high reliability, interactive and structured design.

Educational system measurement is related to communication facilities, attendance, collaborative, and active learning. The elearning system has an evalution of learning outcomes. E-learning information system provides easy and convenient communication facilities, document storage and sharing, contacts and effective and efficient sharing of information with co-workers.

Use of e-learning system for information retrieval, publication of information, storage and sharing of documents, communicate with colleagues and to support lectures. learning system is very useful.

CIQ2: the content and information available in the elearning system is easy to understand.

CIQ3: the content and information available in the elearning system can be relied upon.

CIQ4: the content and information available in the elearning system is timely

CIQ5: the content and information available in the elearning system is accurate.

CIQ6: the content and information available in the elearning system is organized

CIQ1: the content and information available in the elearning system is very useful.

TSQ1 : e-learning system navigation is easy to use

TSQ2 : e-learning system allows me to easily find information

TSQ3: e-learning system is well structured.

TSQ4: e-learning system is easy to use.

TSQ5 : e-learning system has good interactivity

TSQ6 : e-learning system can be accessed quickly

TSQ7 : e-elarning system has good security

TSQ8 : e-learning system has reliability

TSQ9 : e-learning system has a structured design

TSQ10: e-learning system maintenance always maintained well.

TSQ11 : e-learning system has a high degree of flexibility

TSQ12: e-learning system has to ease of integration with other systems

ESQ1: e-learning system has facility to communicate with other students and conduct class discussions such as chat, forums, and more.

ESQ2: e-learning system has attendance facilities to ensure student attendance in classroom.

ESQ3: e-learning system provides collaborative and active learning.

ESQ4: e-learning system has an evaluation of learning and evaluation of outcomes.

ESQ5: e-learning system allows easy and convenient communication with co-workers

ESQ6: e-learning system supports effective and efficient sharing of information with co-workers.

ESQ7: e-learning system allows convenient storage and sharing of documents with co-workers

ESQ8: e-learning system allows me to easily and quickly locate my contact information.

USE1: the extent to which you use e-learning system to retrieve information.

USE2: the extent to which you use e-learning system for information publication.

USE3: the extent to which you use e-learning system to communicate with co-workers

USE4: the extent to which you use e-learning system to store and share documents.

USE5: the extent to which you use e-learning system for course. 
Table 2. Instrument Variable Research

\begin{tabular}{|c|c|c|c|}
\hline $\begin{array}{l}\text { Research } \\
\text { Variable }\end{array}$ & Dimension & Indicator & Source \\
\hline $\begin{array}{l}\text { User Perceived } \\
\text { Satisfaction }\end{array}$ & $\begin{array}{l}\text { Use perceived satisfaction of e-learning system } \\
\text { related to e-learning system to support all field } \\
\text { of study, effective and efficient and overall } \\
\text { satisfied using e-learning system. }\end{array}$ & $\begin{array}{l}\text { UPS1: e-learning system to support your studies. } \\
\text { UPS2: how efficient e-learning system. } \\
\text { UPS3: how effective e-learning system. } \\
\text { UPS4: overall satisfied using e-learning information } \\
\text { system. }\end{array}$ & [6] \\
\hline $\begin{array}{l}\text { Individual } \\
\text { Impact }\end{array}$ & $\begin{array}{l}\text { e-Learning system is very useful, helping users } \\
\text { to simplify and complete tasks faster. E- } \\
\text { learning system increase productivity and is } \\
\text { able to work more effectively and efficiently. }\end{array}$ & $\begin{array}{l}\text { II1: e-learning system allows me to complete tasks } \\
\text { faster. } \\
\text { II2: e-learning system increases my productivity } \\
\text { II3: e-learning system make it easy to complete tasks } \\
\text { II } 4 \text { : e-learning system is useful or my work. }\end{array}$ & [6] \\
\hline
\end{tabular}

The variables in e-learning system quality are technical system quality, content \& information quality, system quality, educational system quality, and service quality. The indicator on the service quality variable is an indicator used in the research [4]-[6], [17], the factors that support the success of the implementation of the Information system and e-learning system at the university. Variable user perceived satisfaction is significantly influenced by technical system quality, content \& information quality, and educational system quality. Technical indicators of quality system, content \& information quality, and educational system quality based on research conducted by [5] about e-learning success model in university. Indicators in use variables, user perceived satisfaction and individual impacts are adapted from research [6] adopted from research [4] on e-learning satisfaction and information systems success theory.

\subsection{Data Collection}

After creating the research instrument and, performing the legibility test. The next process is to collect data. The authors collected data from the respondents through the process of filling out a questionnaire of research conducted online. An online questionnaire is distributed through a questionnaire facility available in e-learning. The results obtained from this stage is the collection of data to be used for the analysis material in the next step.

\section{RESULT AND ANALYSIS}

After collecting the data, the authors perform processing and analysis on the data that has been collected. In the processing, the authors use statistics with multivariate techniques Structural Equation Modeling (SEM). In that technique, the author uses SmartPLS program to process the data. This data analysis phase aims to know the interrelationship between variables in the proposed model. At this stage, the authors also try to answer the question in this research.

\subsection{Demographic of Respondents}

The method used in this research is survey. Respondents who participated 157 e-learning users. The respondents' demographic overview is presented in Table 2 below

Table 3. Summary of Respondent Demographics

\begin{tabular}{llc}
\hline \multicolumn{1}{c}{ Demographics } & \multicolumn{1}{c}{ Attribute } & Percentage (\%) \\
\hline \multirow{2}{*}{ Gender } & Male & 57.32 \\
& Female & 42.68 \\
& Every day & 35.03 \\
Frequency of Use of e-learning & 1 Month & 3.82 \\
& Once a Week More than 1 Month once & 48.41 \\
& 2 weeks & 12.74 \\
& Less than 15 Minutes & 19.11 \\
& 15 minutes to less than 30 minutes & 45.86 \\
Duration of accessing e-learning & 30 Minutes to less than 1 Hour & 24.84 \\
& 1 hour to less than 2 hours & 8.92 \\
& More than 2 hours & 1.27 \\
\hline
\end{tabular}

IJEEI, Vol. 6, No. 3, September 2018 : $281-291$ 


\subsection{Result}

Data processing in this research use Smart PLS 2.0 tools. The first step that needs to be done is to make the path diagram, adapted to the design of the model and the hypothesis that has been formulated previously. This research has 7 latent variables and 44 manifest variables. In addition, there are 11 hypotheses that connect one latent variable with other latent variables. The result of the path diagram created by the author on SmartPLS can be seen in Figure 4.

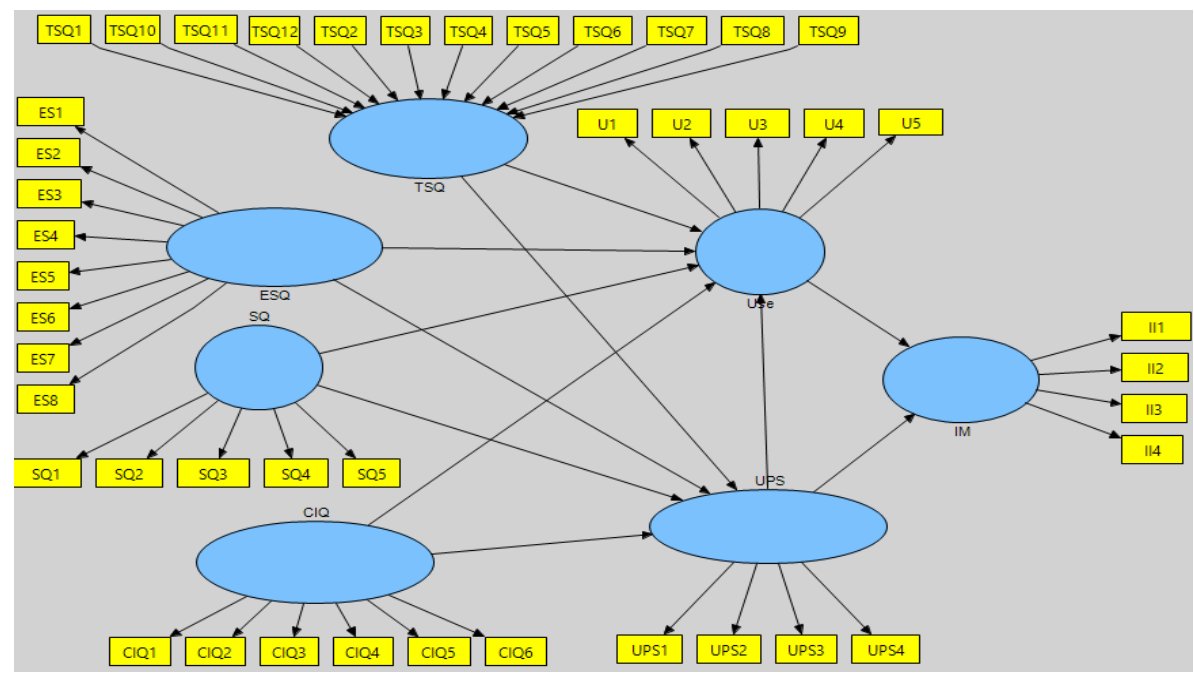

Figure 4. Path diagram

The model in Figure 4 above is evaluated by performing a measurement model and a structural model. Evaluation of measurement model in PLS through three stages, namely, convergence validity test, discriminant validity test, and reliability test which result can be seen in Table 4. Based on data processing with PLS, all latent variables have AVE value> 0.5, one of the convergence validity test requirements.

Table 4. Value Measurement Model

\begin{tabular}{|c|c|c|c|c|c|c|}
\hline Construct & Items & Loading & AVE & CA & $\mathrm{CR}$ & Discriminant Validity \\
\hline Content \& & CIQ1 & 0.781128 & \multirow{6}{*}{0.668424} & \multirow{6}{*}{0.900781} & \multirow{6}{*}{0.923599} & \multirow{6}{*}{ 8 } \\
\hline Information & CIQ2 & 0.839384 & & & & \\
\hline \multirow[t]{4}{*}{ Quality (CIQ) } & CIQ3 & 0.830482 & & & & \\
\hline & CIQ4 & 0.811171 & & & & \\
\hline & CIQ5 & 0.833644 & & & & \\
\hline & CIQ6 & 0.808409 & & & & \\
\hline Educational & ESQ1 & 0.700730 & \multirow{8}{*}{0,560049} & \multirow{8}{*}{0.887119} & \multirow{8}{*}{0.910324} & \multirow{8}{*}{ Yes } \\
\hline System Quality & ESQ2 & 0.756612 & & & & \\
\hline \multirow[t]{6}{*}{ (ESQ) } & ESQ3 & 0.747554 & & & & \\
\hline & ESQ4 & 0.666808 & & & & \\
\hline & ESQ5 & 0.756264 & & & & \\
\hline & ESQ6 & 0.831195 & & & & \\
\hline & ESQ7 & 0.761463 & & & & \\
\hline & ESQ8 & 0.757123 & & & & \\
\hline Individual & II1 & 0.913957 & \multirow{4}{*}{0.759989} & \multirow{4}{*}{0.894386} & \multirow{4}{*}{0.926757} & \multirow{4}{*}{ Yes } \\
\hline \multirow[t]{3}{*}{ Impact (II) } & II2 & 0.832581 & & & & \\
\hline & II3 & 0.892458 & & & & \\
\hline & II4 & 0.825514 & & & & \\
\hline \multirow{5}{*}{$\begin{array}{l}\text { Service Quality } \\
\text { (SQ) }\end{array}$} & SQ1 & 0.891462 & \multirow{5}{*}{0.728780} & \multirow{5}{*}{0.903738} & \multirow{5}{*}{0.931900} & \multirow{5}{*}{ Yes } \\
\hline & SQ2 & 0.906729 & & & & \\
\hline & SQ3 & 0.900447 & & & & \\
\hline & SQ4 & 0.87798 & & & & \\
\hline & SQ5 & 0.671274 & & & & \\
\hline Technical & TSQ1 & 0.616968 & \multirow{6}{*}{0.579226} & \multirow{6}{*}{0.918396} & \multirow{6}{*}{0.931900} & \multirow{6}{*}{ Yes } \\
\hline \multirow{5}{*}{$\begin{array}{l}\text { System Quality } \\
\text { (TSQ) }\end{array}$} & TSQ2 & 0.75037 & & & & \\
\hline & TSQ3 & 0.797187 & & & & \\
\hline & TSQ4 & 0.760619 & & & & \\
\hline & TSQ5 & 0.817091 & & & & \\
\hline & TSQ6 & 0.728549 & & & & \\
\hline
\end{tabular}


Table 4. Value Measurement Model

\begin{tabular}{|c|c|c|c|c|c|c|}
\hline Construct & Items & Loading & AVE & $\mathrm{CA}$ & $\mathrm{CR}$ & Discriminant Validity \\
\hline & TSQ7 & 0.808079 & & & & \\
\hline & TSQ8 & 0.785521 & & & & \\
\hline & TSQ9 & 0.688603 & & & & \\
\hline & TSQ10 & 0.734798 & & & & \\
\hline & TSQ11 & 0.523949 & & & & \\
\hline & TSQ12 & 0.595207 & & & & \\
\hline \multirow[t]{5}{*}{ Use } & U1 & 0.716084 & & & & \\
\hline & U2 & 0.626726 & & & & \\
\hline & U3 & 0.580807 & 0.530184 & 0.704782 & 0.818485 & Yes \\
\hline & U4 & 0.782918 & & & & \\
\hline & U5 & 0.649344 & & & & \\
\hline User Perceived & U1 & 0.716084 & & & & \\
\hline Satisfaction & U2 & 0.626726 & & & & \\
\hline \multirow{3}{*}{ (UPS) } & U3 & 0.580807 & 0.699913 & 0.849913 & 0.901854 & Yes \\
\hline & U4 & 0.782918 & & & & \\
\hline & U5 & 0.649344 & & & & \\
\hline
\end{tabular}

The standardized loading factor for measuring constructs or variables that can not be directly measured actually serves as a good indicator in measuring the construct is 0.7 . Based on table 4 Unqualified indicators, drop and re-calculate. However, some variables have a value of cronbach's alpha $<0.7$. so it needs to do data processing again. If outer loading and outer weight are insignificant, there is no empirical support to maintain that indicator must be eliminated from the model. To make a better approach in multidimensional procedures, the researcher should lower the lowest loading factor once at a time, and repeat this process until it meets the requirements to achieve more than 0.60[15].Therefore, the researcher uses the loading factor value $>0.60$ as the loading factor value to determine the indicator's validity in measuring the construct. all variables with cronbach's alpha and composite reliability are $>0.70$. The test results state that the model can meet the reliability test. So some indicators need to be removed include U3, TSQ11 and TSQ12.

While the structural model evaluation is done through two stages that is to see the value of R-square (R2) from endogenous latent variable and to see t-statistic value by using bootstrap method. The structural model is evaluated by using R-square for the dependent construct and t-Test to determine the actual coefficients of the structural path parameters.

Table 5. R-Square Value

\begin{tabular}{lc}
\multicolumn{2}{c}{ Table 5. R-Square Value } \\
\hline \multicolumn{1}{c}{ Construct } & R Square \\
\hline Content \& Information Quality & \\
Educational System Quality & \\
Individual Impact & 0.550664 \\
Service Quality & \\
Technical System Quality & \\
Use & 0.531445 \\
User Perceived Satisfaction & 0.408999 \\
\hline
\end{tabular}

The result of R-square research in Table 5 gives an Individual Impact (IM) value 0.550664, user perceived satisfaction (UPS) value 0.408999 and use value 0.531445 then R-Square value moderate effects on endogenous latent variables.

To determine whether or not acceptance of a hypothesis can be determined by looking at the significance level of the path coefficient, t-value is generated by running the Bootstrapping algorithm. According to [10], a latent variable has a significant influence on other latent variables if it has a t-value of 1.65 with a significance value of $10 \%$, the value of t-value of 1.96 has a significance of $5 \%$, and the value of $\mathrm{t}$-value of 2.58 has a significance of $1 \%$. The value of path coefficient that is in the range of values of -0.1 to 0.1 is considered insignificant. The results of hypothesis testing in this study can be seen in Table 5 which shows there are 6 accepted hypothesis and 5 others rejected.

Table 6. Hypothesis Testing Result

\begin{tabular}{|c|c|c|c|c|c|}
\hline Hypothesis & Path & Path Coefficient & T-Value & Information & Results \\
\hline H1 & TSQ $\rightarrow$ Use & 0.069064 & 0.536719 & Not significant & Hypothesis Rejected \\
\hline $\mathrm{H} 2$ & $\mathrm{ESQ} \rightarrow$ Use & 0.091170 & 0.897615 & Not significant & Hypothesis Rejected \\
\hline $\mathrm{H} 3$ & $\mathrm{SQ} \rightarrow$ Use & -0.054530 & 0.707477 & Not significant & Hypothesis Rejected \\
\hline
\end{tabular}


Table 6. Hypothesis Testing Result

\begin{tabular}{cccccc}
\hline Hypothesis & Path & Path Coefficient & T-Value & Information & Results \\
\hline H4 & CIQ $\rightarrow$ Use & 0.212535 & 1.696448 & Significant & Hypothesis accepted \\
H5 & TSQ $\rightarrow$ UPS & 0.319487 & 2.484542 & Significant & Hypothesis accepted \\
H6 & ESQ $\rightarrow$ UPS & 0.242574 & 2.151861 & Significant & Hypothesis accepted \\
H7 & SQ $\rightarrow$ UPS & 0.100001 & 0.960001 & Not significant & Hypothesis Rejected \\
H8 & CIQ $\rightarrow$ UPS & 0.091466 & 0.808316 & Not significant & Hypothesis Rejected \\
H9 & UPS $\rightarrow$ Use & 0.494027 & 5.729435 & Significant & Hypothesis accepted \\
H10 & Use $\rightarrow$ II & 0.338279 & 3.352588 & Significant & Hypothesis accepted \\
H1 & UPS $\rightarrow$ II & 0.466813 & 4.973127 & Significant & Hypothesis accepted \\
\hline
\end{tabular}

The following regression equations in this study are made in accordance with the above model:

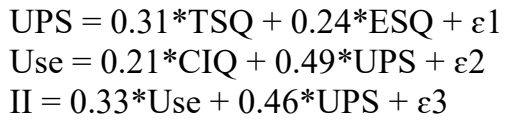

Through regression equation it can be seen that user perceived satisfaction is influenced by technical system quality and educational system quality. Use variable is influenced by content \& information quality, and user perceived satisfaction. Use variable proved most influenced by user perceived satisfaction with a value of 0.49 . Finally, e-learning will affect individual users affected by the use variable with a value of 0.33 and user perceived satisfaction with a value of 0.46 .

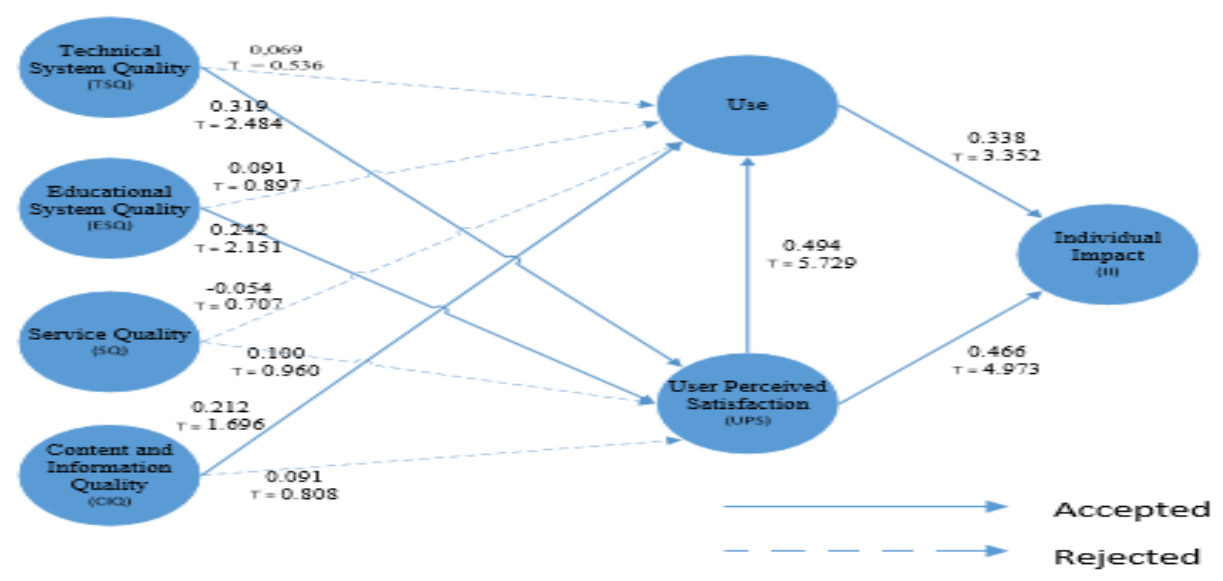

Figure 5. PLS result

Based on figure 5, This research corroborates the developed theories [6]to see the perceived impact of users. In this study, empirical use variable proved to have the highest influence of $52.3 \%$ and user perceived satisfaction of $33.4 \%$ impact on users. The study also found that perceived satisfaction is a major factor driving the use of e-learning systems. This study found that service quality and content \& information quality did not prove to be a factor encouraging users to want to use e-learning and user perceived satisfaction. After analyzing data using SEM method, the final model of this research is as follows.

\subsection{Discussion}

6 out of 11 hypothesized relationships were verified. Use is explained by content and information quality. User perceived satisfaction has a significant influence with technical system quality and educational system quality. Based on the above data processing results, the model describes user perceived satisfaction of $39.8 \%$, the use of e-learning system of $52.3 \%$. Use gives an individual impact of 55\%. The e-learning system is very useful because it helps users to simplify and complete tasks faster and increase effectiveness and efficiency and productivity.

Educational system quality and technical system quality are statistically significant affecting user perceived satisfaction so that H6, H5 is accepted. The effect of the quality of the education system on the perception of the user satisfaction is lower compared to the quality of systems engineering. This indicated the

e-Learning Success Model: An Extention of DeLone \& McLean IS' Success Model (Henki Bayu Seta) 
facilities provided e-learning such as forum, chat, class discussions, has a security, flexibility, ease of integration with other systems and high reliability in the e-learning system can result in user satisfaction. This research confirms MELSS Model, technical system quality and educational system quality influence indirect use through user perceived satisfaction.

Content \& information quality and user perceived satisfaction statistically significant will affect users to use e-learning so that $\mathrm{H} 4$ and $\mathrm{H} 9$ are accepted. Based on the results of data processing, the perception of user satisfaction is higher than the quality of information and content. Perceptions of user satisfaction e-learning information systems greatly affect the use of e-learning system. The use of e-learning system supports the field of study, effective and efficient and overall satisfied using e-learning information system.

Use and user perceived satisfaction are statistically significant and H10, H11 are accepted. Based on the results of data processing, use and user perceived satisfaction gives a positive impact on individual performance and in line with other studies [6][7][12][16]. User perceived satisfaction gives more significant result than use because user perceived satisfaction, lead to achieve personal, educational goals of users and their knowledge will be higher. User perceived satisfaction of e-learning system indicates e-learning system supports field of study, more effective and efficient learning and overall satisfied user using e-learning system. When a user of e-learning system is more satisfied, the use of system will increase.

The results shows that service quality does not significantly affect user perceived satisfaction and use in accordance with the results of research conducted by other researchers [10][11][15][12]. The management must maintain service quality by means of, forming a helpdesk section, providing services and explanations online to assist in the use of e-learning. Result indicates that content and information quality has no significant impact user perceived satisfaction. The content $\&$ information quality should be retrievable, useful, understandable, interesting, and reliable. And educational system quality and technical system quality has no significant impact use.The management need to make continuous improvements to the education system quality factors such as collaborative and active learning, learning outcome evaluation that allows users to view their academic achievement as well as the facilities easy and convenient communication between users of e-learning. In addition, the management must always maintain the quality of the technical system by means of ease of finding information, ease of integration with other systems and high reliability.

\subsection{Implication}

The research on the success of e-learning systems is rarely done in Indonesia context. This research was conducted to build an integrated model of e-learning success in Indonesia. The model that proposed in this study was built by adapting the success model of information systems from DeLone\& McLean which proved in many studies is an appropriate model for assessing the success of information systems in various contextThis research uses modeling D \& M information system success model [3] that has been modified in research [5] and model of e-learning success adoption [6]. Through these two models, this research tries to build a model used to see the success factors of e-learning in universities. This research is conducted to analyze factors that influence the success of e-learning implementation in University. The results obtained by this research can be used as a reference for further research that aims to see the success factor of e-learning in universities. This study only looks at the impact of individuals on the use of e-learning.

This research proves that user perceived satisfaction can be a motivator for the use of e-learning system. The use of e-learning systems has a positive impact on users. Users feel a lot of benefits when accessing e-learning. Therefore, user perceived satisfaction when accessing e-learning can be one of the things that the university needs to pay attention to.

Educational system quality and technical system quality perceived by users proved to encourage the perception of user satisfaction to use e-learning system. Management needs to make continuous improvements to educational system quality factors such as collaborative and active learning, evaluation of learning outcomes that enable users to see academic achievements and easy and convenient communication facilities between e-learning users. In addition, the management must always maintain the technical system quality with the ease of finding information, ease of integration with other systems and high reliability. To improve e-learning users management needs to pay attention to user factors perceived satisfaction and content \& information quality factors.

\section{CONCLUSION}

This research successfully answer research question about success factor of e-learning implementation. Through regression equation it can be seen that user perceived satisfaction is influenced by technical system quality and educational system quality. use is influenced by technical system quality, educational system quality, and user perceived satisfaction. The main factors that drive users to use e- 
learning systems have proven to be most influenced by user perceived satisfaction. Use is influenced by content \& information quality, and user perceived satisfaction. User perceived satisfaction is influenced by technical system quality and educational system quality.

e-Learning will impact on individual users affected by use with a value of $52.3 \%$ and user perceived satisfaction with a value of $39.8 \%$. The study also found that perceived satisfaction is a major factor driving the use of e-learning systems. This study found that service quality and content \& information quality did not prove to be a factor encouraging users to use e-learning and user perceived satisfaction. The results obtained by this research can be used as a reference for further research that aims to see the success factor of elearning in universities.

In this study service quality proved not to give significant influence on the use and user perceived satisfaction. Further research needs to build a deeper theory to include a variable into the model to be tested. Subsequent research needs to expand the scope of the study, such as the number of universities more, representing each region in Indonesia so that will produce more representative models of Indonesia so that learning online and distance can be more optimal. And research that can compare the success model of elearning implementation and evaluate the performance of e-learning both with blended learning education system and online learning.

\section{REFERENCES}

[1] Rentjoko A. Indonesia peringkat kedelapan dalam e-learning [Internet]. 2017 [cited 2018 Apr 27]. Available from: https://beritagar.id/artikel/infografik/indonesia-peringkat-kedelapan-dalam-e-learning

[2] Seta HB, Wati T, Matondang N. Analisis Pengukuran Tingkat Kesiapan Implementasi E-Learning ( E-Learning Readiness ) Studi Kasus : Upn "Veteran" Jakarta. Seminar Nasional Teknologi Informasi dan Multimedia.2016. 2016; 2.5-1-2.5-6.

[3] DeLone WH, McLean ER. Information systems success: The quest for the dependent variable. Information System Research. 1992; 3(1): 60-95.

[4] Delone WH, Mclean ER. The DeLone and McLean Model of Information Systems Success: A Ten-Year Update. Journal of Management Information Systems. 2003; 19(4): 9-30.

[5] Hassanzadeh A, Kanaani F, Elahi S. A model for measuring e-learning systems success in universities. Expert Systems with Applications. 2012; 39(12): 10959-66.

[6] Cidral WA, Oliveira T, Di Felice M, Aparicio M. E-learning success determinants: Brazilian empirical study. Computers \& Education. 2017;

[7] Urbach N, Smolnik S, Riempp G. An empirical investigation of employee portal success. Journal of Strategic Information Systems. 2010; 19(3): 184-206.

[8] Chang JC-J, R. King W. Measuring the Performance of Information Systems: A Functional Scorecard. Vol. 22, Journal of Management Information Systems. 2005. 85-115 p.

[9] Pitt L, Watson R, Kavan C. Service Quality: A Measure of Information System Effectiveness. Vol. 19, MIS Quarterly. 1995. 173-187 p.

[10] Uppal MA, Ali S, Gulliver SR. Factors determining e-learning service quality. British Journal of Educational Technology. 2017; 49(3): 412-26.

[11] Tam C, Oliveira T. Understanding the impact of m-banking on individual performance: DeLone \& McLean and TTF perspective. Vol. 61, Computers in Human Behavior. 2016. 233-244 p.

[12] Aparicio M, Bacao F, Oliveira T. Grit in the path to e-learning success. Computers in Human Behavior. 2017; 66(January): 388-99.

[13] Piccoli G, Ahmad R, Ives B. Web-Based Virtual Learning and a Research Framework Environments : a Preliminary Assessment of Effectiveness in Basic It Skills Training1.MIS Quarterly. 2001; 25(4): (Dec., 2001), pp. 401-426

[14] Sun PC, Tsai RJ, Finger G, Chen YY, Yeh D. What drives a successful e-Learning? An empirical investigation of the critical factors influencing learner satisfaction. Computers \& Education. 2008; 50(4): 1183-202.

[15] Wan Mohamad Asyraf Wan Afthanorhan . Hierarchical component using reflective-formative measurement model in Partial Least Square Structural Equation Modeling (PLS-SEM). International Journal of Mathematics and Statistics Invention. 2014; 2(2): 55-71.

[16] Wu JH, Wang YM. Measuring KMS success: A respecification of the DeLone and McLean's model. Information \& Management. 2006; 43(6): 728-39.

[17] Hossein Mohammadi. Investigating users' perspectives on e-learning: An integration of TAM and IS success modelcomputer in Human Behavior. 2015; 45(1): 359-374. 